\title{
Apontamentos sobre caráter do direito de ação no âmbito do processo civil canônico.
}

\author{
Renato Sedano Onofri.
}

Renato Sedano Onofre compõe o quadro de Professores do Curso de Direito da FICS - Faculdades integradas Campos Salles. É pesquisador da Oficina de artigos da instituição.

\section{Resumo:}

O presente trabalho analisou sucintamente o caráter do chamado direito de ação no ordenamento jurídico canônico. A finalidade de salvação das almas, inerente ao direito da igreja católica, faz do processo uma oportunidade para que se efetivem os cânones, antes que uma oportunidade de efetivar um direito subjetivo. Do mesmo modo, o processo civil canônico admite a relativização do princípio dispositivo, já que sua finalidade transcende o interesse individual das partes. Concluiu-se, por fim, que o direito de ação canônico apresenta caráter publicístico.

Palavras-chave: direito canônico; processo civil; direito de ação; salus animarum.

\begin{abstract}
The research briefly analyzed the feature of the so called right of action at the canonic juridical order. The purpose of the salvation of souls, inherent to the law of the Catholic Church, makes the process an opportunity to actualize the canons, instead of an opportunity to actualize the subjective law. Likewise, the canonic civil process admits the relativization of the principle device, once its finality transcends the individual interest of both parts. Thus we may conclude that the canonic right of action presents a public feature.
\end{abstract}

Keywords: Canonic Law; Civil Process; Right of Action; Salus Animarum.

\section{Introdução}

Já tivemos a oportunidade

de publicar um pequeno trabalho tratando do processo civil romano, analisando de que forma a prática dos atos processuais foram, gradativamente, subtraídos da esfera de atividade privada, em correspondência com o desenvolvimento da cinitas em direção à organização imperial, o que implicou em uma crescente publicização do processo ${ }^{1}$.

\footnotetext{
1 ONOFri, Renato Sedano. A alienação da actio em relação ao indivíduo no direito romano, in Revista Acadêmica Augusto Guz:o, $\mathrm{n}^{\circ}$ 11, 2013. Disponível em http://www.fics.edu.br/index.php/augusto guzzo/arti cle/view/161, último acesso 24/06/2014.
} 


$$
\text { No presente texto, }
$$

continuamos a investigar o tema do

direito de ação, agora no âmbito do direito canônico.

Pode parecer, à primeira vista, que o ordenamento canônico não ofereça um campo fértil a esse tipo de estudo. O sistema jurídico da Igreja católica não é atrelado a uma base territorial, embora esteja ligado a um poder central, cuja expressão máxima é o Papa. Mais do que isso, a principal finalidade do direito canônico não é a pacificação social, como se dá nos

$\mathrm{Na}$ ocasião, tivemos como base, principalmente, as idéias de Giovanni Pugliese e de Piero CALAMANDrei para o desenvolvimento de nosso trabalho.

Giovanni Pugliese, em sua notável obra Actio e diritto subiettivo, afirma a ele parecer que a grande multiplicação das acepções de actio deve-se a um processo de abstração gradual. O processo de abstração pode se sintetizado, conforme o autor, da seguinte forma: 1) ato material (exercício privado e violento das próprias razões); 2) ato material reconhecido juridicamente ou, pelo menos, socialmente (autodefesa privada, disciplina em sua forma exterior); 3) tipo de procedimento ou esquema processual (meio para agere); 4) pode de agir, seja exercitando a autodefesa, seja valendo-se de um esquema processual (Pugliese, Giovanni. Actio e diritto subiettivo. Milano: Giuffrè, 1939, pág. 19, nota de rodapé $\mathrm{n}^{\mathrm{o}} 2$ ).

As ideias de Pugliese amoldam-se às de CALAMANDREI, que expõe com brilhantismo a relatividade do conceito de ação. Ação, direito de ação (e também a actio) são conceitos cujo conteúdo não é revelado em si mesmo, mas a partir do estado das relações entre indivíduo e poder público, cidadão e Estado, entre liberdade e autoridade. Para o autor, portanto, procurar o verdadeiro sentido de ação é uma fadiga em vão, uma vez que ele dependerá do contexto do ordenamento. Por fim, CALAMANDrei aponta como mais o mais equilibrado dos posicionamentos aquele de Chiovenda, que estabeleceria uma relação bem ajustada entre interesse individual e poder público (CALAMANDrei, Piero. La relatività del concetto d'azione, in Opere giuridiche, vol. 1. Napoli: Morano, 1965). ordenamentos estatais: sua razão última é a salvação da alma (salus animarum $)^{2}$.

$$
\text { Portanto, o fundamento e }
$$

a finalidade do direito canônico não são os mesmos do direito romano e, igualmente, não são os mesmos dos ordenamentos nacionais contemporâneos.

Do mesmo modo, a juridicidade do direito da Igreja não é aferível da mesma forma nos ordenamentos estatais. Já houve quem defendesse ser o direito, propriamente dito, aquele emanado exclusivamente do

2 Nesse ponto é necessário que se atente para a diferença entre direito canônico e direito eclesiástico, pois, se a finalidade precípua do direito canônico é a salus animarum, a do direito eclesiástico não é. Há uma dualidade institucional da Igreja, na medida em que, se é um corpo místico encabeçado por Cristo, é, também, composta por homens, constituindo uma comunidade social. Dessa forma, o fim do direito eclesiástico é "reger o relacionamento da Igreja enquanto considerada Estado, nos assuntos políticos de natureza diplomática (direito público externo), bem como nas relações jurídicas (civis e penais) com os habitantes do Vaticano (direito público interno)". O direito canônico, por sua vez, toma a Igreja como instituição puramente religiosa, visando a "disciplinar o relacionamento entre ela e seus subordinados pela fé, uma vez que professam a doutrina do cristianismo. O escopo precípuo do direito canônico, portanto, é a salvação das almas" (Tucci, José Rogério Cruz e; Azevedo, Luiz Carlos de. Lições de processo civil canônico - bistória e direito vigente. São Paulo: RT, 2001, pág. 14)

No mesmo sentido, conforme SANTIAgo PANIzO Orallo, a conclusão a que se chegou no Concílio Vaticano II: "Cristo, que é o único Mediador entre Deus e o homem, instituiu e mantém na terra a sua Igreja, comunidade de fé, esperança e amor, como um todo visível. Porém, a sociedade provida de seus órgãos hierárquicos e o Corpo místico de Cristo, assembléia visível e a comunidade espiritual, a Igreja terrestre e a Igreja enriquecida com os bens celestiais, não devem ser consideradas como duas coisas distintas ou superpostas, mas sim formam uma realidade complexa que está integrada por um componente humano e outro divino" (Orallo, Santiago Panizo. Ratio iuris-ratio salutis. Uma tensión dialéctica em busca del equilíbrio justo - la razón del derecho em la iglesia al servicio de la razón de la justicia y de la salvación del hombre, in Ius canonicum, n ${ }^{\circ} 91$, vol. XLVI. Pamplona: Universidad de Navarra, 2006, pág. 213 - tradução livre) 
Estado, o que excluiria a juridicidade do ordenamento canônico. Mais do que isso, já foi afirmada a incompatibilidade entre a fé cristã e a estrutura hierarquizada do direito. São os casos, por exemplo, de RudulF SOHM e KARL BARTH, para quem, em linhas gerais, a essência da igreja é espiritual, enquanto a essência do direito é terrena; além de que, com base na doutrina cristã protestante, afirmou-se que Cristo é o "solus Sanctus", "solus Dominus", e os demais homens, não podem ser mais do que servos, pecadores, excluindo-se deles qualquer possibilidade de santidade, de autoridade e de verdade, de modo que existiria uma insolúvel incompatibilidade entre a causalidade humana e a causalidade divina ${ }^{3}$.

\section{Foi Del Giudice,} baseado na ideia de SANTI ROMANO de que o conceito de instituição é o único necessário e suficiente para delinear em termos exatos o direito, que iniciou corrente de pensamento a favor do caráter jurídico das normas canônicas ${ }^{4}$.

Entende-se, contudo, de acordo com CAPOGROSSI, que também a Igreja, como todo fato da vida em sociedade, enquanto obedece a um princípio de verdade e de razão, coloca-se

3 Para uma síntese dessa polêmica v. OrALlo, Santiago Panizo. Ratio iuris-ratio salutis (...), op. cit. (ntoa 2), págs. 211-213.

${ }^{4}$ Cfr. Fedele, Pio. Diritto canonico, in Enciclopedia del diritto. Milano: Giuffrè, 1964, págs 871-872. como ordenamento; de fato, a Igreja, impondo uma finalidade necessária, geral e comum a todos os seus membros, faz com que esses ajam com determinada ética para manterem-se fiéis àquela finalidade, aplicando esforços aos sacrifícios impostos ao seu alcance; a Igreja é ordenamento na medida em que se põe e se afirma frente a uma sociedade ${ }^{5}$.

Assim, temos que tais peculiaridades do direito canônico, em vez de constituírem óbice, em verdade, justificam o estudo do direito de ação neste âmbito. Pretendemos demonstrar como a ação assume, no ordenamento da Igreja, um caráter altamente publicístico.

No trabalho a respeito da alienação da actio no processo romano ${ }^{6}$, concluímos que a actio só assume um caráter verdadeiramente público na última fase de desenvolvimento do processo civil no Império Romano (extraordinaria cognitio), quando já contava com uma estrutura burocrática razoavelmente desenvolvida e funcionários estatais para cumprir as funções que antes ficavam a cargo dos indivíduos? ${ }^{7}$.

\footnotetext{
${ }^{5}$ Idem, Ibidem, pág. 872.

${ }^{6}$ Cfr. OnOfri, Renato Sedano. $A$ alienação (...), op. cit. (nota 1).

7 Contudo, deve-se assinalar que diversos historiadores questionam a existência de uma burocracia realmente eficiente, mesmo no tardo império. Ver, por exemplo, Garnsey, Peter; SALLeR, Richard. The roman empire economy, society and culture, London: Duckworth, 1987, em
} 


$$
\text { Em relação ao processo }
$$

civil canônico, a despeito de não haver uma organização imperial assentada em uma base territorial, como houve em Roma, a ação serve mais, segundo nos parece, à própria Igreja que ao indivíduo.

O trabalho será dividido em três partes: na primeira delas, promoveremos um olhar panorâmico sobre as definições legislativas e doutrinárias de ação no âmbito da canonística, enfatizando que uma primeira leitura pode dar a falsa idéia de se estar diante de uma concepção privatista de ação; na segunda parte, avançaremos sobre as mitigações do princípio dispositivo no âmbito do processo canônico, como tentativa de demonstrar de que modo as finalidades do direito canônico penetram no processo, a despeito de ser esse o campo do direito menos afeito à teologia moral da Igreja ${ }^{8}$; por fim, esboçaremos algumas linhas, com base em FERnANDo DeLLA RocCA, procurando relacionar ação e

que os autores afirmam, em um capítulo denominado "Government without bureaucracy", que "they [os romanos] did not, however, develop an imperial administration that matched the dimensions of the empire" (pág. 20). A respeito, também, KELLY, Christopher. Ruling the late roman empire. Cambridge: Havard University Press, 2004.

${ }^{8}$ Cfr. TuCCI, José Rogério Cruz e; Azevedo, Luiz Carlos de. Lições de processo civil canônico - história e direito vigente, São Paulo: RT, 2001, pág. 51: "O direito processual canônico recebeu, desde cedo, marcante influência das fontes romanas, por ser a matéria mais distante do elemento teológico-moral que impregnava o ordenamento jurídico da Igreja", salus animarum, e como essa "publiciza" a ideia daquela.

\section{1- $\quad$ Definiçõoes de ação na canonística}

Não são muitos os trabalhos específicos sobre o direito de ação no âmbito do processo canônico. E, entre esses raros trabalhos, são ainda mais escassos aqueles que analisam o tema sob o prisma de que aqui queremos tratar, isto é, o caráter publicístico ou privatista do direito de ação no processo canônico ${ }^{9}$.

O cân. 1667 do Código de Direito Canônico de 1917 continha disposição interessante sobre a ação: "quodlibet ius non solum actione munitur, nisi aliud expresse cautum sit, sed etiam exceptione, quae semper competit et est suapte natura perpetua" (todo direito está protegido não só pela ação, a não ser que, expressamente outra coisa seja determinada, mas também pela exceção, que sempre pode ser oposta e é perpétua por sua natureza).

O Código de Direito Canônico de 1983 manteve a mesma disposição no cân. 1491, suprimindo a

\footnotetext{
${ }^{9}$ Destaca-se a boa análise contida no artigo de FERNANDO DELla RocCA, Il diritto di azione nell'ordinamento canonico, in Saggi di diritto processuale canônico. Padova: CEDAM, 1961, de que trataremos mais adiante.
} 
expressão relativa à natureza perpétua da exceção ("quae semper competit et est suapte natura perpetua"), que passou para o cân. $1492, \int 2^{010}$.

\section{Chama atenção a}

proximidade da redação de ambos os dispositivos canônicos com a norma contida no art. 75 do Código Civil brasileiro, de 1916: "a todo direito corresponde uma ação que o assegura ${ }^{11}$ ".

A redação do dispositivo do Código de Direito Canônico parece ser mais tecnicamente perfeita que a do Código Civil brasileiro. Não obstante, o espírito de ambas as normas, pelo menos se tomadas isoladamente em relação ao ordenamento em que se inserem, é exatamente o mesmo: ligar ao direito a ação, entendida, nesse caso, em sentido material.

Entendida dessa forma, não se pode deixar de reconhecer certo caráter privatista à definição de ação do

10 Doravante, por economia, evocaremos o Código de Direito Canônico de 1983 apenas por CIC 1983, e o Código de 1917, por CIC 1917.

${ }^{11}$ Nos comentários ao art. 75 do Código Civil de 1916, Clóvis Bevilaqua afirmava que "a acção é parte constitutiva do direito, tecido tegumentar, que protege a parte nuclear do interesse, desdobra-se em ação no sentido processual de ius persequendi in iudicio quod nobis debetur". Aduz, ainda, "a quem a lei reconhece um direito, pelo mesmo facto, lhe reconhece a faculdade de reclamar a intervenção do poder judiciário para defender o direito ameaçado ou restaurar o violado. Não ha direito sem acção" (Bevilaqua, Clóvis. Código civil dos Estados Unidos do Brazil comentado, vol I, São Paulo: Francisco Alves, 1916, pág. 333). O autor, portanto, deixa de considerar como direitos aqueles mutilados, bem como os decorres de fato jurídico cuja eficácia é uma relação obrigacional natural.
CIC 1917/1983 ${ }^{12}$. A ação em sentido material não se confunde com a pretensão à tutela jurídica, com o chamado direito de ação. Com efeito, Pontes de Miranda, quando se refere à primeira escreve, simplesmente ação; quando se refere à segunda, escreve "ação", com a utilização de aspas. Para esse autor, a ação é exercida, principalmente, por meio da "ação", exercendo-se a pretensão à tutela jurídica do Estado. Ou seja, a ação, entendida em sentido material, é exercida, principalmente, por meio do exercício do direito de ação, com o exercício da pretensão à tutela jurídica estatal. Mas não só: a coerção jurídica não é sempre judicial $^{13}$. Por exemplo, o art. 502 do Código Civil de 1916, correspondente ao art. $1210, \$ 1^{\circ}$ do Código Civil vigente: “o possuidor turbado, ou esbulhado, poderá manter-se ou restituir-se por sua própria força, contando que o faça logo; os atos de defesa, ou de desforço, não podem ir

\footnotetext{
12 Nesse sentido Jesus Hortal, nos comentários ao CIC 1983: "ao pretender ação, os autores se dividem entre os partidários do caráter privado e os de caráter público. Para os primeiros, a ação é parte integrante do direito subjetivo e vai dirigida a obter do particular o cumprimento de sua obrigação. Esta parece ser a noção herdada do direito romano pelo direito canônico, inclusive no novo Código (destaque nosso). Os partidários da teoria do caráter público da ação argumentam que sua finalidade não é dar satisfação aos particulares, mas cumprimento à lei. Por isso, vai dirigida à autoridade pública, solicitando que faça cumprir a lei" (HorTal SÁnCHEZ, Jesus. Código de direito canônico (trad. port. Conferência Nacional dos Bispos do Brasil), 9ª ed., São Paulo: Loyola, 2008, pág. 363).

13 Pontes De Miranda, Francisco Cavalcanti. Tratado de direito privado, tomo V, $4^{\mathrm{a}}$ ed., São Paulo: RT, 1974, pág. 478.
} 
além do indispensável à manutenção, ou restituição da posse".

Vê-se que, nesse caso, há exercício da ação, que corresponde a direito subjetivo material, sem que se tenha recorrido ao poder judiciário, por meio do direito subjetivo de ação.

Se há fechamento do caminho judicial ou administrativo, não deixa de haver ação (em sentido material); "a ação não é a constelação dessas "ações"; mas o sol do sistema" ${ }^{14 "}$.

Portanto, para Pontes de Miranda, a deductio in iudicium é acidental na vida da ação. "Tão acidental, tão estranha ao conteúdo daquela ( $=$ tão anterior é ela ao monopólio da justiça pelo Estado), que se pode dar (e é freqüente dar-se) que se deduzam em juízo ações que não existem, tendo o Estado, por seus juízes, de declarar que não existem, ou não existiam quando foram deduzidas ${ }^{15}$ ".

Pode ser esse o sentido do cân. 1667 do CIC 1917, ora reproduzido no vigente CIC 1983, no cân. 1491? Talvez, se tomarmos uma interpretação isolada do dispositivo; contudo, um olhar sistemático, levando em conta os fins do processo e do próprio direito canônico revela uma idéia um pouco diversa.

\footnotetext{
${ }^{14}$ Idem, Ibidem, pág. 480.

15 Idem, Ibidem, pág. 481.
}

É possível encontrar, contudo, posições privatistas e outra publicísticas, no âmbito da doutrina processual canonística ${ }^{16}$.

$$
\text { Veja-se, por exemplo, }
$$

García Faílde, que, conscientemente ou não, dá à ação um caráter, em princípio, privatista: "todos os canonistas fazem sua a definição romana de Celso em D.44, 7, 51, definindo a ação como 'o direito (subjetivo) ou faculdade (subjetiva) que um indivíduo tem de perseguir, por meio do processo, o que é devido e lhe é negado ou posto em perigo ${ }^{17}$ '.

\section{Domínguez, Morán e} Anta, em comentários ao CIC 1917, por sua vez, aduziam que, antigamente, a ação era vista como meio de dirimir controvérsias surgidas entre particulares por conta de uma lesão a um direito. A ação processual era tida como um elemento integrante do direito ou como meio de realizar o mesmo direito, e a reagir contra a violação. Prosseguem os comentaristas afirmando que, atualmente, pelo contrário, considera-se o processo

16 Pode ser questionável o uso dos termos público e privado no âmbito do direito canônico, por não se tratar de um direito relacionado a um Estado nacional propriamente dito. Não obstante, manteremos o uso dos termos para facilitar a compreensão do tema tratado, até porque a própria doutrina processual canonística utiliza o binômio para explicitação de suas ideias.

17 GARCía FAÍlDE, Juan José. Nuevo derecho procesal canónico - estudio sistemático analítico comparado, $3^{\mathrm{a}}$ ed., Salamanca: Publicaciones Universidad Pontificia, 1995, pág. 25, tradução livre. Deve-se fazer um reparo, contudo: García Faílde fala em "todos" os canonístas, o que, certamente, não está correto, uma vez que não há tal consenso na doutrina a respeito do conceito de ação. 
como uma instituição de interesse público, cuja finalidade predominante não é a satisfação dos direitos subjetivos, mas o cumprimento da lei ordenada a procurar o bem comum ${ }^{18}$.

Assim, a ação, para os autores pode ser vista como uma oportunidade levada à autoridade pública para que essa intervenha fazendo respeitar e cumprir a vontade da lei quando não se cumpre ou não de pode cumprir voluntariamente a prestação. É, então, um direito autônomo, não independente, em relação ao direito subjetivo; a intervenção coativa judicial para o cumprimento denomina-se ação, que difere do direito controvertido ${ }^{19}$.

Vê-se que os comentaristas do Código, mesmo sem procurarem justificativas na natureza e finalidade do direito canônico, acabam por apresentar a ação e o processo civil da Igreja por meio de uma visão altamente publicística.

\section{Também Manuel J.}

Arroba Conde dá contornos publicísticos a sua definição de ação. Em um primeiro momento, o autor elabora um conceito meramente formal, afirmando ser a ação "o primeiro ato solene, isto é a

18 Domínguez, Lorenzo Miguélez; Morán, Sabino Alonso; Cabreros Anta, Marcelino. Código de derecho canónico bilíngüe y comentado, $3^{\mathrm{a}}$ ed., Madrid: Editorial Católica, 1949, pág. 624.

19 Idem, Ibidem, loc. cit. apresentação do libelo (...)”. Prossegue, todavia, aduzindo que nesse ato é "sublinhado o caráter de publicidade, como direito a pedir a intervenção do juiz para aplicar a lei numa controvérsia concreta $^{20 \prime}$.

$\mathrm{O}$ autor ainda procura desvincular direito subjetivo e ação afirmando que a expressão nisi aliud expresse cautum sit, contida no cân. 1491, evidencia que não se podem identificar as figuras $^{21}$.

Percebe-se, com isso, que buscar qual o caráter da ação no âmbito do processo civil canônico com base apenas na disposição do cân. 1491 do CIC 1983 não é possível. Há necessidade de um olhar mais sistemático, mais panorâmico, para que se possa ter uma ideia mais clara em relação a uma eventual feição privatista ou publicística da ação no âmbito do direito da Igreja.

Procuraremos, a partir de agora, verificar de que forma as finalidades peculiares do ordenamento canônico penetram no processo civil, analisando o princípio dispositivo e suas mitigações.

\footnotetext{
20 Arroba Conde, Manuel J. Diritto processuale canonico, trad. port. Martin Segú Génova, Direito processual canônico, $5^{\mathrm{a}}$ ed., São Paulo: EDIURCA, 2006, pág. 303.

21 Idem, Ibidem, loc. cit.
} 
2- $\quad$ Finalidade do processo civil canônico e princípio dispositivo.

Ao analisar o processo civil canônico, não se pode deixar de ter em vista as peculiaridades que o cercam, quando comparado ao processo civil laico.

Não se pode esquecer, por exemplo, o disposto no cân. 1419, \ $1^{\circ}$ : "em cada diocese e para todas as causas não expressamente excetuadas pelo direito, o juiz de primeira instância é o Bispo diocesano, que pode exercer o poder judiciário pessoalmente ou por outros, segundo os cânones seguintes".

Essa disposição, segundo nos parece, não é, meramente, uma norma de organização judiciária. O fato de o Bispo exercer função jurisdicional revela que tal função é, também, pastoral, imiscuindo-se na própria finalidade última da Igreja, que é a salvação da alma.

Com efeito, Carmelo de Diego-Lora ensina nesse sentido. Como Pastor da Igreja, interessa ao Bispo, em primeiro lugar, que, nas relações que surjam no âmbito de sua competência, e os conflitos que em razão dessas relações se produzam, sejam vivenciados e resolvidos guardando-se, em todo momento, a eqüidade canônica e tendo em conta a salvação das almas, quae in
Ecclesia suprema semper Lex esse debet (cf. cân. 1752) ${ }^{22}$.

É dizer, o Bispo, ao julgar, deve ter em vista a finalidade última da Igreja católica e do direito canônico, o que implica, também, em dizer que sua função pastoral está intimamente ligada à ordenação do processo canônico.

Tal função pacificadora, no entanto, não impede que o juiz, em certos casos, coloque-se diante do objeto de enfrentamento entre duas pessoas em uma demanda, extinguindo a controvérsia jurídica por meio de uma sentença, respondendo adequadamente a cada dúvida enunciada pelas partes. Isso exige que o juiz se mantenha à margem dos interesses de autor e réu, alheio a qualquer sinal de parcialidade que torne suspeita de injustiça a sentença. Basta lembrar que as partes, sentindo-se prejudicadas, têm o direito de apelar; em certas hipóteses, cabe, inclusive, um reexame necessário da sentença ante $\mathrm{o}$ tribunal superior. $\mathrm{O}$ objeto em litígio não pertence ao juiz, mas às respectivas partes, que formularam seus arrazoados fundados no direito ${ }^{23}$.

22 Diego-Lora, Carmelo de. Independencia y dependência judiciales em el nuevo código, in Ius canonicum, $\mathrm{n}^{\mathrm{o}} 55$, vol. XXVIII, Pamplona: Universidad de Navarra, 1988, págs 351-352.

No mesmo sentido, V. PIETRo. La función directiva del juez en la instrucción de la causa, in Ius canonicum, $\mathrm{n}^{\circ}$ 67, vol. XXXIV, Pamplona, Universidad de Navarra, janeirojunho 1994, pág. 74, nota de rodapé no 10 .

23 Diego-Lora, Carmelo de, op. cit., pág. 352. A referência no texto ao chamado 'reexame necessário' é, 
Por outro lado, se o juiz deve ser independente em relação às partes, é dependente em relação à lei. Está submetido à lei, até o ponto de, em tema de especial importância (cân. 1075), a própria lei universal da Igreja fazer reserva expressa para evitar que uma mal aplicada justiça do caso concreto possa vulnerar a ordem justa que na sociedade eclesiástica o ordenamento canônico trata de instaurar e manter ${ }^{24}$.

\section{Entretanto, esse princípio} não derroga o fato de que o juiz, fundado na aequitas possa abrandar os rigores $\mathrm{da}$ lei para evitar que se cometa uma iniquidade; a submissão à lei só força o juiz a uma mais atenta consideração do sistema legal em seu trabalho de interpretação, e a uma mais detida ponderação em relação a sua decisão, já que as sentenças devem sempre ser fundadas no direito ${ }^{25}$.

\section{Continua o autor,} aduzindo que preservar a independência

no CIC 1983, a hipótese do cân. 1682, \ $1^{\circ}$ : "a sentença que primeiramente tiver declarado nulo o matrimônio, juntamente com as apelações, se houver, e com os outros autos do juízo, seja transmitida ex officio ao tribunal de apelação, no prazo de vinte dias após a publicação da sentença".

Os processos que declaram a invalidade de matrimônio no âmbito do direito canônico são objeto de especial interesse público, assim como, no ordenamento laico, interessam, particularmente, os que condenam entes da administração direta e indireta, assim como aquelas que dão procedência aos embargos à execução fiscal de dívida ativa da Fazenda Pública. Tanto que, nessas hipóteses, conforme o Código de Processo Civil brasileiro, há, do mesmo modo, reexame necessário após a sentença de primeira instância (cfr. art. 475 , inc. I e II).

${ }^{24}$ Diego-Lora, Carmelo de, op. cit., pág. 353.

${ }^{25}$ Idem, Ibidem, loc. cit. judicial tem sido um dos problemas mais vivos para a processualística moderna, problema esse de que não se furta a doutrina processual canônica. Tem-se procurado fortificar a independência desde o interior mesmo do próprio processo $^{26}$.

Chiovenda, conforme Diego-Lora, defendia que o único modo necessário de preservar a imparcialidade judicial é o princípio dispositivo, entendido em sua plenitude, isto é, abarcando também a proposição da prova. Sustenta-se que a independência só é garantida se se fizer depender o juiz das atitudes processuais e iniciativas que as partes adotem no processo. $\mathrm{O}$ juízo objetivo e acertado que se expressa na sentença é como o fruto nascido da dialética própria do contraditório; as posições contrapostas sustentadas pelas partes geram uma situação de enfrentamento entre interesses incompatíveis, que faz possível que o juízo seja pronunciado com total imparcialidade ${ }^{27}$.

Tal postural doutrinária, contudo, ainda segundo o autor, não carece de objeções possíveis. É notável que a conivência das partes pode levar a processos simulados ou em fraude à lei. Apesar da pretendida imparcialidade do

\footnotetext{
${ }^{26}$ Idem, Ibidem, loc. cit.

${ }^{27}$ Idem, Ibidem, pág. 354.
} 
juiz, seu juízo ficaria determinado pela parcialidade dos aparentes litigantes. Para evitar casos assim, sustenta-se que o juiz deve buscar, por seu próprio poder jurisdicional, inquirir a verdade objetiva sobre a que o convencimento deve formar-se. E isso, sustenta Diego-Lora, não mitiga sua imparcialidade ${ }^{28}$.

Diego-Lora não está
sozinho ao defender a mitigação do
princípio dispositivo no âmbito do
processo canônico. De forma mais
incisiva, Vicente Pietro afirma que
somente quando o juiz eclesiástico se
envolva realmente no empenho de
averiguar a verdade, o processo e a
sentença se convertem em autêntico
instrumento de justiça. Mais ainda se se
tem em conta que, em muitas ocasiões, as
pessoas que recorrem aos tribunais
eclesiásticos não têm a possibilidade de
contar com uma adequada assessoria
técnica (limitações econômicas,
sobretudo, o impedem) que, durante o
processo, assuma, com a ciência devida, o
que é próprio da iniciativa da parte ${ }^{29}$.

A busca por uma verdade objetiva e a ideia de que o processo é uma série de atos que se encadeiam para esse fim, leva Diego-Lora a ver o processo canônico como uma instituição jurídica, o que significa, na visão do autor,

${ }^{28}$ Idem, Ibidem, pág. 355.

${ }^{29}$ Pietro, Vicente, op. cit., pág. 66. um encadeamento de atos jurídicos de relevância e natureza públicas na Igreja. Tal conjunto de atos ou série de atos tende a realização de uma ideia objetiva de natureza permanente, que preside teleologicamente todo o processo em sua inspiração e desenvolvimento. Essa ideia é a realização da justiça do caso concreto, mediante a aplicação da lei canônica a uma verdade objetiva. Não basta, portanto, que se satisfaça o fim do processo unicamente por encontrar o juiz uma verdade meramente formal ${ }^{30}$.

$$
\text { No mesmo sentido, }
$$

Vicente Pietro, para quem o único interesse do juiz no processo deve ser o da busca da verdade e, a esse fim se ordenam todos os instrumentos que o direito lhe outorga.

O processo canônico, por isso, aparece como contencioso; a lei processual se articula sobre o suposto de que haja uma parte autora e outra demandada. O juiz coloca-se sobre as elas, garantindo que haja um enfrentamento limpo, de acordo com as normas previstas pelo direito para esse tipo de evento.

Muitas vezes, contudo, falta ao processo caráter rigorosamente contencioso; é o caso, por exemplo, de uma ação de invalidação de casamento

${ }^{30}$ Diego-Lora, Carmelo, op. cit., pág. 358. 
em que ambos os cônjuges estejam de acordo sobre a invalidade e sua causa ou causas.

A razão última do esquema processual contencioso está, conforme Pietro, no afã de alcançar a verdade. Entende-se, então, que apenas o enfrentamento, ou a possibilidade de que ele ocorra, permite, no terreno dialético da prova submetida ao contraditório, alcançar a finalidade última do processo, que é, justamente, a verdade real.

$$
\mathrm{O} \text { autor adverte que a }
$$
experiência demonstra ser mais difícil, nos processos em que não ocorre uma verdadeira confrontação, alcançar a verdade objetiva, uma vez que, sem enfrentamento, as provas podem ser forjadas, acomodadas.

Não pode o juiz, portanto, atuar passivamente, como um expectador. Sua função, nesse caso, se limitaria a garantir o reto uso das ferramentas processuais, a espera do conjunto de provas que apresentem as partes. Cair-se-ia em um esquema demasiado formalista, em pouquíssima sintonia com o ministério da verdade.

Assim, o papel do juiz, não pode ser limitado a garantir $\mathrm{O}$ contraditório, o direito de defesa, ficando tranqüilo com o simples fato de que deu às partes a possibilidade de contraditar as provas aduzidas ou de apresentar outras novas. Isso não garante que se chegue à verdade objetiva; garante, antes, os direitos processuais das partes. Mas esses mesmo direitos não visam outra coisa, que não o conhecimento da verdade ${ }^{31}$.

Desse modo, de acordo com Diego-Lora, o ofício pastoral do juiz deve levá-lo não a ver a lei pela lei, não o juízo pelo juízo, mas lei e juízo a serviço da verdade, da justiça, da paciência, e da caridade. Alcançar essa verdade objetiva, incorporada pelas alegações das partes e pela prova no processo, para que possa ser conhecida pelo juiz e para que esse possa sobre ela emitir um juízo, exige um procedimento humano próprio que faz da pessoa investida no ministério judicial um executor responsável ${ }^{32}$.

A finalidade do processo, no sentido da busca de uma verdade objetiva, influência não só no papel do juiz, mas de todos os atores processuais. Cada um daqueles que desempenha um papel, um ato, nesse encadeamento processual, deve agir de modo a que se chegue, sempre, a esse fim institucional. Por exemplo, o defensor do vínculo no processo de nulidade de matrimônio não deve sempre argumentar pro validitate matrimonii, mas sempre pro rei veritate. Por tal princípio, o defensor é incumbido de defender o vínculo

\footnotetext{
31 Pietro, Vicente, op. cit., págs. 67-73.

32 Diego-Lora, Carmelo de, op. cit., pág. 359.
} 
matrimonial, não de forma absoluta, mas subordinadamente ao fim processual, que é a investigação e o resultado da verdade objetiva $^{33}$.

\section{Da mesma forma, o} advogado não pode abandonar o interesse em fazer triunfar seu cliente, mas não pode se subtrair do único e comum objetivo final, que é a afirmação da verdade de fato. Em certo sentido, juiz, promotor de justiça, advogado, defensor do vínculo, no foro eclesiástico, prestam, reciprocamente, igual cooperação, sem mesclar os ofícios próprios de cada um, pretendendo alcançar o mesmo fim ${ }^{34}$.

\section{A atuação do Ministério} Público e do defensor do vínculo, no processo canônico, serve, além da tarefa de tutelar o bem público, para manter os juízes o mais independentes quanto possível em relação aos interesses

33 Idem, Ibidem, loc. cit. O ofício do defensor do vínculo está enunciado no cân. 1432 do CIC 1983: "para as causas em que se trata da nulidade da ordenação ou da nulidade ou dissolução do matrimônio, constitua-se na diocese o defensor do vínculo, a quem cabe, por obrigação, defender, propor e expor tudo o que razoavelmente possa ser aduzido contra a nulidade ou a dissolução".

34 Diego-LorA, Carmelo de, op. cit., pág. 360. No mesmo sentido Paulo Moneta, para quem a parte legitimamente chamada ao juízo tem o dever de responder, de constituir, eventualmente, um procurador próprio diante do juiz, não só para fazer valer as próprias razões, mas também para fornecer todos aqueles elementos úteis para a procura da verdade. Tais deveres assumem, portanto, no direito canônico, uma particular intensidade, especialmente naquelas causas, que são sem dúvida a maioria, em que entra em jogo não só o interesse individual, mas aquele de toda a comunidade. (MONETA, Paulo. Processo canônico - processo giudiriario, in Enciclopedia del diritto, Milano: Giuffrè, 1987, pág. 891). particulares. Contudo, deve-se notar que, em uma perspectiva institucional do processo, há de se reconhecer ao juiz certa iniciativa judicial, sobretudo em matéria probatória ${ }^{35}$.

Com efeito, o CIC 1983 expressamente reconhece a possibilidade e, para alguns casos, o dever, de o juiz diligenciar para obtenção de provas, suprir negligências das partes e, até, opor exceções em nome delas ${ }^{36}$.

\section{No entendimento de} Vicente Pietro, o cân. 1452 implica em um equilíbrio saudável entre princípio inquisitivo e princípio dispositivo ${ }^{37}$. A direção do processo, segundo o autor, não é o simples arbitramento para sejam respeitadas as regras do jogo, mas uma função verdadeiramente diretiva do juízo, buscando a completa instrução que sirva como ponto de apoio a uma sentença justa $^{38}$.

\footnotetext{
35 Diego-Lora, Carmelo de, op. cit., pág. 361.

36 Cfr. cân. 1452, \ $1^{\circ}$ : "em negócio que interessa unicamente a particulares, o juiz pode proceder somente a requerimento da parte. Todavia, uma vez legitimamente introduzida a causa, o juiz pode e deve proceder também ex officio nas causas penais e em outras referentes ao bem público da Igreja ou à salvação das almas

$\int 2^{\circ}$ - Contudo, o juiz pode, além disso, suprir a negligência das partes na apresentação de provas ou na oposição de exceções, sempre que o julgar necessário para evitar uma sentença gravemente injusta, salvas as prescrições do cân. 1600".

37 Para Carmelo de Diego-Lora, encontram-se no CIC 1983 disposições que expressam, de um lado, o princípio dispositivo (cân. 1533; 1536, \$1 $1^{\circ}$; 1551 e 1552; 1581 e 1768), que, por sua vez, é contrabalanceado por expressões do princípio inquisitivo (cân. 1530; 1545; 1553 e 1559-1563; 1570 e 1574; 1575 e 1578, \$3; 1582; 1600; 1679 e 1680). (Diego-Lora, Carmelo de, op. cit., pág. 362)

38 PIETRO, Vicente, op. cit., pág. 74.
} 
O autor invoca Mons.

Stankiewicz, aduzindo que o cân. 1452 enfraquece, sim, o princípio dispositivo em sentido processual, mas que não o substitui, por completo, pelo princípio inquisitivo, já que as provas trazidas por iniciativa das partes ou do juiz, ficam igualmente sujeitas ao contraditório. Nas causas que respeitam diretamente à salus animarum não seria justificada a atitude passiva do juiz, uma vez que, como se disse para o processo civil, "fixados os fatos a acertar, o modo de acertá-los não pode depender da vontade das partes, sendo a verdade apenas uma" (Chiovenda, Principi di diritto processuale civile, Napoli, 1980 - ristampa del 1923). O juiz suprir a negligência da parte ao produzir as provas e em opor exceções, demonstra o caráter pastoral de seu ofício a serviço da verdade, a busca de que é ordenado o processo canônico e que é o fundamento, mãe e lei da justiçą ${ }^{39}$.

Do ponto de vista dogmático, justificam-se os poderes inquisitivos do juiz em vista da necessidade de se obter certeza, inclusive moral, para o proferimento da sentença ${ }^{40}$.

\footnotetext{
39 Idem, Ibidem, pág. 74, nota de rodapé no 10.

40 Nesse sentido, Vicente Pietro: "toda la normativa en la materia apunta, por lo demás, a que el juez obtenga la necessaria certeza sobre el mérito da causa. Certeza que no es posible alcanzar si no se tiene el 'conocimiento suficiente de la causa' (cfr. can. 1599, 2) o, com palabras del can. 1606, el 'pleno conocimiento de la cuetión', hasta donde humanamente resulte posible" (PIETRO, Vicente, op. cit. pág. 75).
}

A certeza moral que o juiz deve adquirir se forma apoiando-se no alegado e provado (cân. 1608); porém, não necessariamente o provado provém do aporte das partes mesmas: pode proceder também da prova que o juiz leve ao processo, uma vez que ele, apesar de ter que preservar sua imparcialidade, não pode se furtar de buscar o fim processual, qual seja, a verdade objetiva. Assim, toda prova levada ao processo, independentemente do sujeito que a produza ou concorra para sua produção, pertence, com efeito, ao próprio processo $^{41}$.

Conclui Diego-Lora aduzindo que o juiz deve desejar cumprir seu ofício no espírito que o Código alenta e evitar algumas hipóteses a que o cân. 1457 culmina sanções. Assim, só pode o juiz se valer do $\int 2^{\circ}$ do cân. 1452 dentro das seguintes condições: a) evitar que se chegue a pronunciar uma sentença injusta; b) deverá precisar quais os motivos concretos que para que se esteja a temer uma sentença injusta; c) deve indicar quais atos das partes, que manifestem a negligência, deseja suprir; e d) que não implique, com seu ato, qualquer forma de pré-julgamento (cân. $1607-1612)^{42}$.

\footnotetext{
${ }^{41}$ Diego-Lora, Carmelo de, op. cit., pág. 361.

42 Idem, Ibidem, pág. 363.
} 
Vemos, portanto, que o juiz canônico, bem como as partes, procuradores, defensores do vínculo, promotores, advogados, devem concorrer para o fim maior do processo, que é a busca da verdade objetiva. Com efeito, mesmo o princípio dispositivo é mitigado em nome dessa finalidade maior.

Demonstra-se, com isso, que a penetração dos fins da Igreja no direito processual implica em uma publicização desse. Se as figuras processuais, bem como a atuação do juiz, são moldadas para satisfazer uma finalidade maior, que não é, meramente, a satisfação de um interesse privado, também o conceito de ação será modelado nesse sentido, ou seja, com viés público.

Passemos, agora, a analisar o conceito de ação permeado pela finalidade da salus animarum, com base no pensamento de Fernando Della Rocca.

\section{3- $\quad$ Ação e salus animarum}

Em vista do que até aqui expusemos, pode-se dar razão a Fernando Della Rocca quando afirma que, do ponto de vista canônico, o direito de ação não pode ser valorado segundo o chamado critério historicista ${ }^{43}$.

Como vimos, as doutrinas que trataram do tema da natureza do direito de ação, em especial Piero Calamandrei, acentuam que o problema não pode ser formulado em termos absolutos. Deve, mais corretamente, ser posto apenas historicamente, em vista de um determinado ordenamento positivo em uma certa fase de seu desenvolvimento.

Della Rocca afirma que, segundo essa opinião, quando se examina o direito de ação na estrutura política da comunidade social, está-se a examinar aquela que é a relação fundamental que se passa entre os elementos da comunidade; mais precisamente, entre aqueles que exercem ativamente a autorictas e aqueles que, passivamente, são vinculados a tal autorictas. Isso porque o processo civil é sempre, no fundo, como observa Calamandrei, um só problema: "aquele das relações entre interesse individual e interesse público, entre cidadão e Estado, entre liberdade e autoridade ${ }^{44 ”}$.

Essa linha de pensamento não pode, contudo, ser transportada sic et simpliciter para o direito canônico, já que, no âmbito da Igreja, substitui-se a

43 Della Rocca, Fernando. Il diritto di azione nell'ordinamento canonico, in Saggi di diritto processuale canonico, Padova: CEDAM, 1961, pág. 177.

${ }^{44}$ Idem, Ibidem, págs. 177-178. 
palavras "cidadão" por Christifideles, e ao poder do Estado, a dupla potestade de ordem e de jurisdição da Igreja ${ }^{45}$.

No item 2, pode-se perceber que entre o direito laico e o direito canônico há uma diversidade de fins, de condutas, de formas, tais que não se pode por nos mesmo termos a controvérsia, muito embora haja um substrato comum entre ambos, que é justamente o conteúdo humano.

Assim, se no campo civilístico, a visão historicista permite entender o problema do ponto de vista positivo, isto é, as teorias sobre a ação também focalizam o conteúdo político que necessariamente têm nos vários períodos históricos a relação entre liberdade e autoridade, no âmbito do direito canônico, permite entender o problema apenas do ponto de vista negativo, ou seja, conforme a fórmula anti-historicista: apenas assim se faz possível, e largamente útil, no que se refere ao direito de ação, aquele motivo fundamental inspirador do ordenamento da Igreja, que é o salus animarum ${ }^{46}$.

Em vista de tal princípio, Della Rocca afirma que a ação tem, no direito canônico, o caráter de direito-dever subjetivo. Compreende-se porque é um direito; é direito-dever, contudo, pois,

${ }^{45}$ Idem, Ibidem, pág. 178.

46 Idem, Ibidem, loc. cit. embora o direito do indivíduo contra um órgão da Igreja não deva ser entendido sempre como juridicamente controlado, há sempre um dever imposto pela finalidade da instituição Igreja. Se o exercício da ação não é coercível no ordenamento civil, o direito mesmo representa uma particular responsabilidade no ordenamento canônico. O direito não perde, sob o aspecto rigorosamente jurídico e salvo casos especiais, a nota de incoercibilidade; contudo, o elemento moral, quando não jurídico, do dever induz a converter a nota de incoercibilidade jurídica naquela de auto coercibilidade moral ${ }^{47}$.

Assim, o direito do cristão, individualmente considerado, contra o órgão jurisdicional da Igreja é de se considerar ut supra, como um direito dever posto, na sua profunda essência teleológica, a serviço da suprema finalidade institucional da Igreja: a salus animarum $^{48}$.

Nos termos propostos por Calamandrei para a controvérsia entre a concepção publicística e privatista do direito de ação, em que se responderia se a ação é um direito do indivíduo frente ao poder público para ter adimplido dever correspondente ao seu direito, ou

\footnotetext{
${ }^{47}$ Idem, Ibidem, pág. 180.

48 DelLa Rocca, Fernando. Azione - diritto canonico, in Enciclopedia del diritto, Milano: Giuffrè, 1959, págs. 829830.
} 
uma oportunidade do poder público para fazer efetivo o direito objetivo, no âmbito do direito canônico, em vista da finalidade maior da salus animarum, devese concluir pela segunda resposta.

\section{Conclusão.}

\section{Todo ordenamento} jurídico responde a determinados pressupostos ideológicos e culturais que justificam, com maior ou menor coerência, o sentido das estruturas por ele delineadas e as respostas que oferece para a solução dos conflitos entre os sujeitos que integram o grupo social em que se encontra vigente cada sistema de direito. Tornar-se-ia de todo impossível que um jurista pretendesse compreender determinado ordenamento sem tomar consciência de tais pressupostos, independentemente de que, pessoalmente - no exercício de sua liberdade intelectual e religiosa - , concorde com eles ou os rejeite ${ }^{49}$.

Com efeito, tem razão o Prof. Lombardía nas palavras iniciais de seu manual.

Como vimos, a leitura isolada do cân. 1491 poderia induzir-nos a concluir pelo caráter privatista do direito de ação no âmbito do direito canônico. Um olhar sobre as mitigações do princípio dispositivo, da finalidade do processo e do próprio direito canônico, contudo, revelam que a ação tem um sentido completamente diverso neste contexto.

Pio Fedele defende a natureza exclusivamente pública de todo o ordenamento canônico. Para ele, a diferenciação entre direito público e direito privado não só é estranha ao direito canônico, como todo o direito canônico deve ser considerado como público.

$\mathrm{Na}$ visão de Fedele, falta no ordenamento canônico qualquer referência às relações ou fenômenos jurídicos em que se possa configurar o interesse dos homens considerados uti singuli. $\mathrm{O}$ indivíduo está em posição de sujeição a uma exigência e a um fim,

49 LombardíA, Pedro. Lecciones de derecho canónico, 1984, trad. port. Alda de Anunciação Machado, Lições de direito canônico, São Paulo: Loyola, 2008, págs. 15-16. 
quais sejam, a repressão dos pecados e a salvação da alma, ambos de natureza publicística. A tutela jurídica não se presta a salvaguardar os interesses do homem uti singuli, mas sempre uti universi, com vistas a um fim espiritual superior, sobrenatural ${ }^{50}$.

Com isso, encerramos este pequeno e despretensioso trabalho, por meio do qual pudemos concluir que o fim maior proposto pela Igreja à sociedade de fiéis por ela regida, atribui, não só ao direito de ação, mas ao processo como um todo, caráter eminentemente público, consistindo não só em um direito do indivíduo de conseguir o cumprimento da prestação, mas, sobretudo, uma oportunidade para fazer efetivo o ordenamento da Igreja, com vistas à salvação da alma.

\section{Bibliografia}

Arroba Conde, Manuel J. Diritto processuale canonico, trad. port. Martin Segú Génova, Direito processual canônico, $5^{\mathrm{a}}$ ed., São Paulo: EDIURCA, 2006.

Bevilaqua, Clóvis. Código civil dos Estados Unidos do Brazil comentado, vol I, São Paulo: Francisco Alves, 1916.

CALAmANDReI, Piero. La relatività del concetto d'azione, in Opere giuridiche, vol. 1, Napoli: Morano, 1965

${ }^{50}$ Fidele, Pio, op. cit, pág. 881.
Della Rocca, Fernando. Azione - diritto canonico, in Enciclopedia del diritto, Milano: Giuffrè, 1959.

. Il diritto di azione nell'ordinamento canonico, in Saggi di diritto processuale canonico, Padova: CEDAM, 1961

Diego-LorA, Carmelo de. Comentário exegético al código de derecho canónico, vol. IV/1, $3^{a}$ ed., Pamplona: Universidad de Navarra, 2002.

Independencia $y$ dependência judiciales em el nuevo código, in Ius canonicum, $\mathrm{n}^{\circ}$ 55, vol. XXVIII, Pamplona: Universidad de Navarra, 1988.

La tutela procesal de los derechos en la iglesia, in Ius canonicum, $\mathrm{n}^{\mathrm{o}}$ 67, vol. XXXIV, Pamplona, Universidad de Navarra, janeiro-junho 1994

Domínguez, Lorenzo Miguélez; MorÁn, Sabino Alonso; CABreros ANTA, Marcelino. Código de derecho canónico bilingüe y comentado, $3^{\mathrm{a}}$ ed., Madrid: Editorial Católica, 1949

Fedele, Pio. Diritto canonico, in Enciclopedia del diritto, Milano: Giuffrè, 1964.

García FAÍlDe, Juan José. Nuevo derecho procesal canónico - estudio sistemático analítico comparado, $\quad 3^{\mathrm{a}} \quad$ ed., Salamanca: Publicaciones Universidad Pontificia, 1995.

Hortal SÁnCHEz, Jesus. Comentários ao código de direito canônico (trad. port. Conferência Nacional dos Bispos do Brasil), 9ª ed., São Paulo: Loyola, 2008.

LOMBARDíA, Pedro. Lecciones de derecho canónico, 1984, trad. port. Alda de Anunciação Machado, Lições de direito canônico, São Paulo: Loyola, 2008. 
Moneta, Paulo. Processo canônico - processo giudiziario, in Enciclopedia del diritto, Milano: Giuffrè, 1987.

Orallo, Santiago Panizo. Ratio iuris-ratio salutis. Uma tensión dialéctica em busca del equilíbrio justo - la razón del derecho em la iglesia al servicio de la razón de la justicia y de la salvación del hombre, in Ius canonicum, $\mathrm{n}^{\circ}$ 91, vol. XLVI, Pamplona: Universidad de Navarra, 2006.

PIETRO, Vicente. La función directiva del juez. en la instrucción de la causa, in Ius canonicum, $\mathrm{n}^{\mathrm{o}}$ 67, vol. XXXIV, Pamplona, Universidad de Navarra, janeiro-junho 1994.

Tucci, José Rogério Cruz e; AzEvedo, Luiz Carlos de. Lições de processo civil canônico - bistória e direito vigente, São Paulo: RT, 2001. 